\title{
Hydrological anomalies connected to earthquakes in southern Apennines (Italy)
}

\author{
E. Esposito ${ }^{1}$, R. Pece $^{2}$, S. Porfido ${ }^{1}$, and G. Tranfaglia ${ }^{3}$ \\ ${ }^{1}$ Consiglio Nazionale delle Ricerche, Geomare sud, Via Vespucci 9, 80142 Napoli, Italy \\ ${ }^{2}$ Dipartimento di Scienze della Terra, Università di Napoli Federico II, Largo S. Marcellino, 10, 80138 Napoli, Italy \\ ${ }^{3}$ Servizio Idrografico e Mareografico Nazionale, Compartimento di Napoli, Via Marchese Campodisola 21, 80133 Napoli, \\ Italy
}

Received: 14 May 2001 - Revised: 27 September 2001 - Accepted: 17 October 2001

\begin{abstract}
The study of hydrological variations in the watersheds of seismic areas can be useful in order to acquire a new knowledge of the mechanisms by which earthquakes can produce hydrological anomalies. Italy has the availability of many long historical series both of hydrological parameters and of seismological data, and is an ideal laboratory to verify the validity of theoretical models proposed by various authors.
\end{abstract}

In this work we analyse the hydrological anomalies associated with some of the big earthquakes that occurred in the last century in the southern Apennines: 1930, 1980 and 1984. For these earthquakes we analysed hydrometric and pluviometric data looking for significant anomalies in springs, water wells and mountain streams. The influence of rainfalls on the normal flows of rivers, springs and wells has been ascertained. Also, the earthquake of 1805 , for which a lot of hydrological perturbations have been reported, is considered in order to point out effects imputable to this earthquake that can be similar to the effects of the other big earthquakes.

The considered seismic events exhibit different modes of energy release, different focal mechanisms and different propagation of effects on the invested areas. Furthermore, even if their epicentres were not localised in contiguous seismogenetic areas, it seems that the hydrological effects imputable to them took place in the same areas. Such phenomena have been compared with macroseismic fields and transformed in parameters, in order to derive empirical relationships between the dimensions of the event and the characteristics of the hydrological variations.

The results of this work point to a close dependence among hydrological anomalies, regional structures and fault mechanisms, and indicate that many clear anomalies have been forerunners of earthquakes. In 1993, the Naples Bureau of the Hydrographic National Service started the continuous monitoring of hydrologic parameters by a network of automatic stations and transmission in real time; presently 7 acquifers are under control in which also $\mathrm{pH}, T$, salinity, elec-

Correspondence to: R. Pece (pece@unina.it) trical conductivity, dissolved oxygen are measured. We envisage to increase the number of monitoring sites and controlled parameters.

\section{Introduction}

Information on hydrological variations associated with seismic events (anomalies, such as increase or decrease of spring and river flows, the rising or lowering of the water level in wells) concomitant and/or preceding seismic events has been widely known for at least 2000 years. In the last decades some hydrological anomalies have been used as earthquake precursors (Savaresky and Rikitake, 1972; Scholtz et al., 1973; Rikitake, 1974, 1975; Whitehead et al., 1985; Chengmin, 1985; Mogi, 1987; Kissin and Grinevsky, 1990; Igarashi et al., 1992). One of the best examples is the Haicheng earthquake in 1975, when a lot of hydrological anomalies occurred before the earthquake and the city was then evacuated (Molnar et al., 1976).

Also in Italy, a possible correlation between earthquakes and piezometric anomalies has been recognised (Albarello et al., 1991; Albarello and Martinelli, 1994; Onorati and Tranfaglia, 1994; Onorati et al., 1994; Pece et al., 1999; Esposito et al., 1998a, 1999). Many other documents of the XVIII and XIX centuries report information regarding variations of water levels and spring flows in occurrence with earthquakes.

Only in the last two decades have the hydrological variations been related to the characteristics of seismic sources. Various interpretative models (Gold and Soter, 1985; Bredehoeft et al., 1987; King and Muir-Wood, 1993; Muir-Wood and King, 1994; Briggs, 1994; Curry et al., 1994; Rojstaczer and Wolf, 1994) indicate how the fluctuations of the water level in wells and the variations in the flow of springs and/or mountain rivers can be used as earthquake precursors and, moreover, to characterise the mechanisms of the seismic source, because they are significantly influenced by the deformation field associated with the earthquake. In particular, 


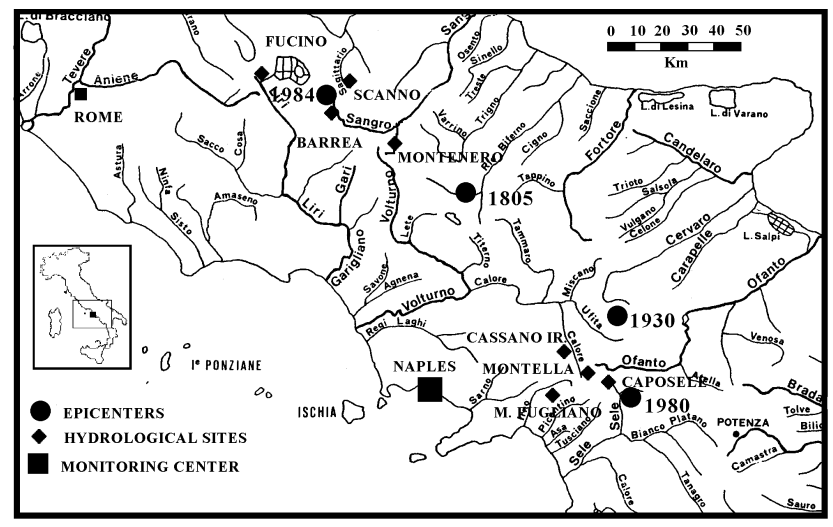

Fig. 1. Sketch map of southern Italy illustrating the Monitoring Center in Naples and the mentioned hydrological sites. Also, the four epicenters of the studied earthquakes are indicated.

King and Muir-Wood (1993) recently proposed a model of the deformation associated with the dislocation phenomena in complex systems of faults with different mechanisms and orientations. According to this model, the coseismic dislocation during strong earthquakes produces a notable deformation of the superficial crust (surface layers) which influences directly the superficial acquifers. Therefore, the hydrological regime and the spatial variation of anomalies are correlated to the spatial variation of the volumetric deformation produced by the phenomena of the coseismic dislocation in a wide area.

Furthermore, some authors tried to classify the possible "shapes" of the hydrological anomalies and to find some relationships among magnitude, precursor time and distance from epicentre of the hydrological anomalies. Kissin and Grinevsky (1990) examined carefully many hydrological anomalies reported in various parts of the Earth. Also, Chengmin (1985) examined many anomalous variation precursors of 60 earthquakes with $M>6.0$ in China. They found essentially that: (1) most of these anomalies took place at distance less than $50 \mathrm{~km}$ from the epicentres; (2) their number decreases rapidly at a growing distance from the epicentre; (3) the type or the "shape" of the anomaly depends on the fault type, topography, magnitude and distance from the epicentre, the time before and/or after the earthquake. Kissin and Grinevsky (1990) classified some typical shapes of hydrological anomalies: $57 \%$ of the anomalies consist of a generalized depression of groundwater levels, $24 \%$ and $12 \%$ are stepwise increases and decreases, respectively, of groundwater levels, and $7 \%$ are complex variations. The groundwater level variations can be $0.5 \mathrm{~cm}-16 \mathrm{~m}$, but $76 \%$ are comprised between $1 \mathrm{~cm}$ and $1 \mathrm{~m}$.

Also many hydrological variations were reported by Rojstaczer and Wolf (1994) for the Loma Prieta earthquake in 1989: groundwater levels in the highland parts of the drainage basins were lowered for a long time, while most of the streamflow increased within $15 \mathrm{~min}$ after the earthquake, indicating that the earthquake increased the rock permeabil- ity and temporarily enhanced groundwater flow rates. In 1993, the Naples Bureau of Hydrographic National Service started the continuous monitoring of hydrologic parameters by a network of automatic stations in real time transmission. This network (Tranfaglia, 1994; Onorati and Tranfaglia, 1996) consists of 82 stations, 7 repeaters and the acquisition Centre in Naples, controlling a total of 175 sensors (26 ultrasonic hydrometers on bridges, 63 rain gauges, 23 thermometers, 13 hygrometers, 5 barometers, 4 anemometers, 6 water level gauges). All the data from the sensors are transmitted at the Monitoring Centre in Naples where they are continuously controlled, visualised and stored (Fig. 1). We hope that this monitoring can furnish clearly the evidence that hydrological anomalies are forerunners of earthquakes in the controlled areas.

\section{Earthquakes in southern Apennines}

The areas considered in this work constitute nearly all of the southern part of the Apennine Chain from the Molise Region to the Lucania (Basilicata) Region. The seismicity in this section of the Apennine Chain is characterised by severe seismic events with intensities greater than IX MCS. In this work we analyse the hydrological anomalies associated with some of the strong earthquakes that occurred in the last centuries in southern Apennines:

- 1984 (Southern Abruzzo, 7-11 May)

- 1980 (Irpinia-Basilicata, 23 November)

- 1930 (Irpinia, 23 July),

- 1805 (Molise, 26 July).

For the most recent earthquakes (1980 and 1984), we analysed hydrometric and pluviometric data from 1972-1992 looking for significant anomalies in springs, water wells and mountain streams. The influence of rainfalls on the normal flows of rivers, springs and wells has been statistically verified. With regards to the older earthquakes (1805 and 1930), we considered the historical sources contemporaneous to the seismic event and we could classify types and entities of hydrological phenomena strictly imputable to the earthquake.

The considered seismic events show different modes of energy release, different focal mechanisms and different propagation of effects on the invested areas. Furthermore, even if their epicentres were localised in seismogenetic, and not the contiguous areas, it seems that the hydrological effects imputable to them took place in the same areas.

Such phenomena have been compared at first with macroseismic field and subsequently transformed in parameters, in order to derive empirical relationships between the dimensions of the event and the characteristics of the hydrological variations.

The first results of this work point to a close dependence among hydrological anomalies, regional structures and fault mechanisms. 


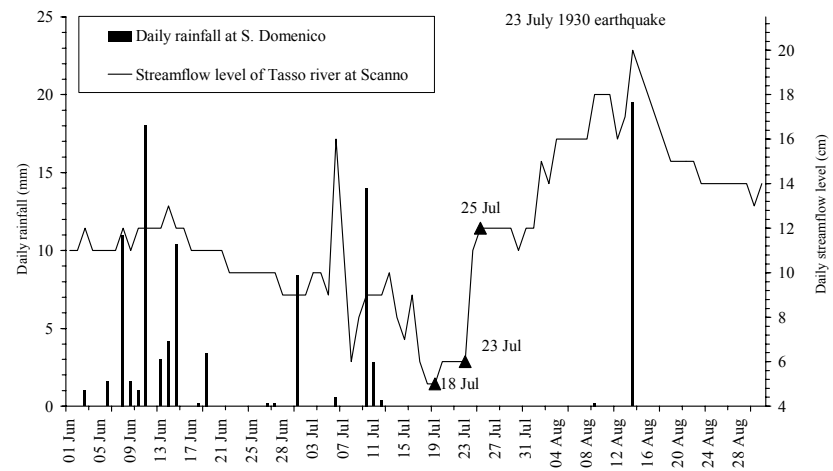

Fig. 2. Hydrological anomaly correlated to the 23 July 1930 earthquake, consisting of a sharp decrease a few days before the seismic event followed by a strong increase of the streamflow level of the Tasso River measured at Scanno.

\section{Discussion}

\subsection{The Molise earthquake of July 1805}

The 26 July 1805 earthquake happened inside the Molise seismogenetic zone (Alessio et al., 1993), where various strong earthquakes (greater than X MCS) took place, like those in 346, 848 and December 1456. At present, the seismicity is constituted by low magnitude swarms, like the sequence at Isernia in January 1986, with $M_{\max }=4.0$ and that of Sannio-Matese in March 1997 with $M_{\max }=4.6$ (Alessio et al., 1990).

This strong earthquake was felt in all of southern Italy and damaged more than 200 cities and villages in the Molise and Campania regions. The macroseismic epicentre is localised in the Molise zone, between Isernia and Campobasso; the highest intensity of XI MCS was at Frosolone (Isernia district). The effects of this earthquake before, during and after the main shock are particularly interesting. We collected the descriptions of a lot of phenomena possibly linked to the seismic event; in fact, starting from the XVII century, the interest of naturalists to analyse and interpret the seismic phenomenon, and also the attention on the effects of earthquakes, increased; as a consequence, both the number of reports and the accuracy in the descriptions of strange phenomena grew considerably. The many historical sources allow one to understand and point out types and entities of the phenomena directly imputable to this earthquake. Fractures, landslides, liquefaction, hydrological variations in springs, rivers and wells are distributed in the area of VII MCS. The details in the descriptions of the earthquake's effects allow one to distinguish a temporal succession of such effects: in particular, in the phase preceding the earthquake, variations of hydrological parameters, flow rate and chemical composition in some localities in Molise have been reported; besides the hydrologic variations (anomalies), other numerous coseismic effects have been observed: ground effects, as fractures and landslides (Esposito et al., 1987, 1995, 1998b; Michetti et al., 2000). Flow increases have been observed

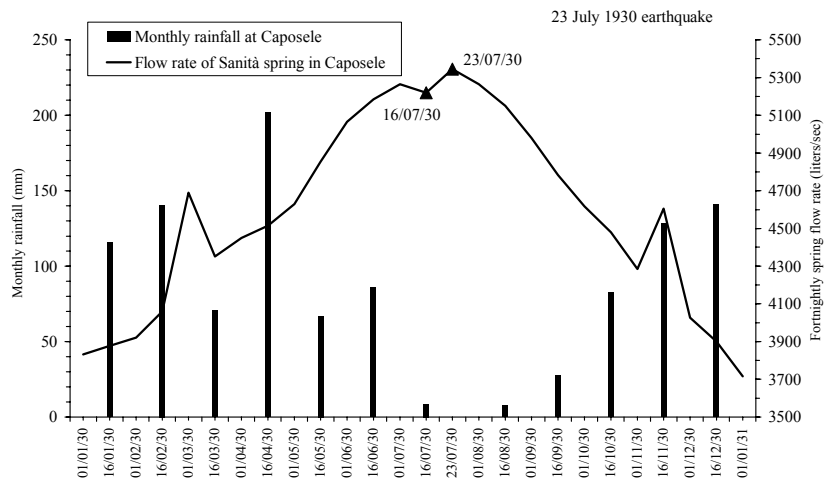

Fig. 3. Hydrological anomaly correlated to the 23 July 1930 earthquake, consisting of an increase in the flow rate of Sanità Spring at Caposele of about $1501 / \mathrm{s}$.

in more than 16 springs, mostly SSW of the Matese Mountains. Contemporaneously, 4 new springs appeared at S. Salvatore Telesino (Caserta district), Morcone (Benevento district), Matese Mountains and Boiano (Campobasso district). The new spring in Boiano was active for about 2 months after the seismic event.

\subsection{The earthquake of July 1930}

The 23 July 1930 earthquake, erroneously defined as "the Vulture earthquake", destroyed almost entirely many villages in Eastern Irpinia, causing severe damages also in the Benevento, Foggia and Potenza provinces. The victims were more than 1400 and the wounded were about 10000 . The main shock happened at 00:08 GMT with the greatest intensity of X MCS and a magnitude $M s=6.7$, followed by many aftershocks, some of which with intensity of VII MCS. Numerous and impressive phenomena on the physical environment were observed in the villages of Andretta, Aquilonia, Ariano Irpino, Bisaccia, Calitri, Flumeri, Melfi, Trevico, San Giorgio la Molara, Vallata, Villanova del Battista and Zungoli.

To reconstruct the effects on the environment caused by this strong earthquake, we started to: (1) research methodically all the documents relative to it; (2) to analyse critically the administrative and technical reports in the Record Offices and in Civil Engineer Offices of Avellino and Salerno cities and in the Municipal Technical Offices of the towns around the epicentre. Furthermore, all the information from local and national newspapers have been collected.

The critical examination of the seismological knowledge at that time completed this investigation in order to better understand the collected information. The comparison between the bibliographic sources and the unpublished reports allowed us to draft the map of the coseismic geological effects: landslide phenomena, hydrological anomalies, soil fractures and surficial tectonic breaks.

This investigation revealed that the greatest number of the seismic effects were found in the isoseismic area of VIII MCS (Esposito et al., 2000; Porfido et al., 2001). Two hy- 
drological anomalies are shown in Figs. 2 and 3 for the Tasso River and one spring at Caposele.

In Fig. 2 the hydrological anomaly correlated to the 1930 earthquake consists of a sharp decrease in the streamflow a few days before the seismic event, even if high rainfalls preceded this decrease. Also, the increase after the seismic event seems to be an anomalous hydrological behaviour of the springs that contribute to the Tasso River.

In Fig. 3 an increase of 150 1/s in the flow rate of Sanità Spring at Caposele was noted in the measurements carried out a few hours after the seismic event with respect to the measurements carried out on 16 July 1930, a week before the earthquake.

\subsection{The earthquake of November 1980}

The 23 November 1980 earthquake happened inside a seismically active band extending from southern Abruzzo to Lucania (Basilicata). This Campanian-Lucanian seismogenetic zone is characterised by a complex seismotectonic structure, buried under the thick alloctonous terrains that constitute the Apennine Chain.

On the basis of geological, structural and geophysical evidences, the seismogenetic band has been subdivided into more seismogenetic zones (Scandone et al., 1990; Alessio et al., 1993, 1995) characterised by a frequent seismicity, both historical as the earthquakes in 1561, 1694, 1851, 1857, 1930 with I $\geq$ IX MCS and recent, main shock-aftershock type, as the earthquakes in 1980, 1990, 1991 with I $\geq$ VIII and $5 \leq \mathrm{M} \leq 6.9$.

About 800 villages were damaged in Campania and Lucania. The Imax was X MSK. This great intensity and the nature of the geological structures caused very numerous effects. Surface fractures were observed in all the areas from the epicentre until to the VIII isoseismal line. About 200 landslide phenomena were observed in an area more than $20000 \mathrm{~km}^{2}$ wide around the epicentre (Esposito et al., 1998b).

The study of the hydrological effects has been carried out on:

- measurements of water levels in 9 wells with 3 days periodicity;

- spring flows measured each day;

- streamflow levels measured each day;

- continuous registration of water level in rivers.

We also considered many other similar, but less continuous measurements carried out during 1975-1985 (periodicity varied from weekly to monthly) on minor springs and rivers.

Seven of the about 30 greatest springs exhibited a clear anomaly. Most of them are in the high Sele River and on Matese Mountains.

Before the earthquake, the trends of hydrometric levels were normal or decreasing, but showed a general increase

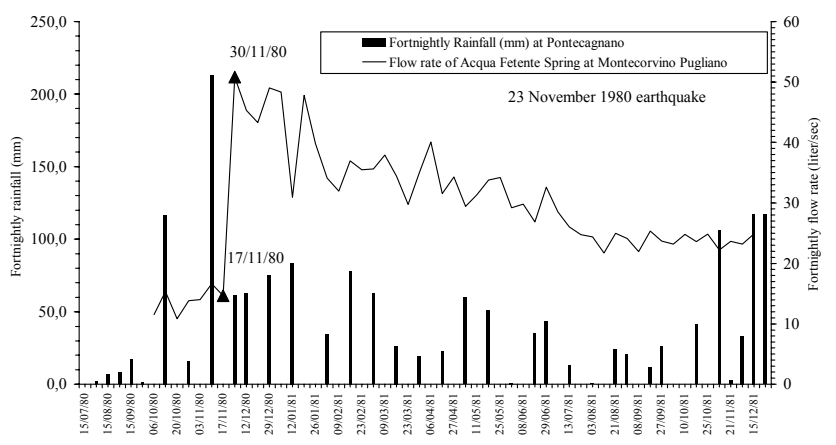

Fig. 4. Hydrological anomaly correlated to the 23 November 1980 earthquake, consisting of a great increase in the flow rate of Acqua Fetente Spring at Montecorvino Pugliano from 14.7 to 50.8 1/s. This variation lasted for more than one year.

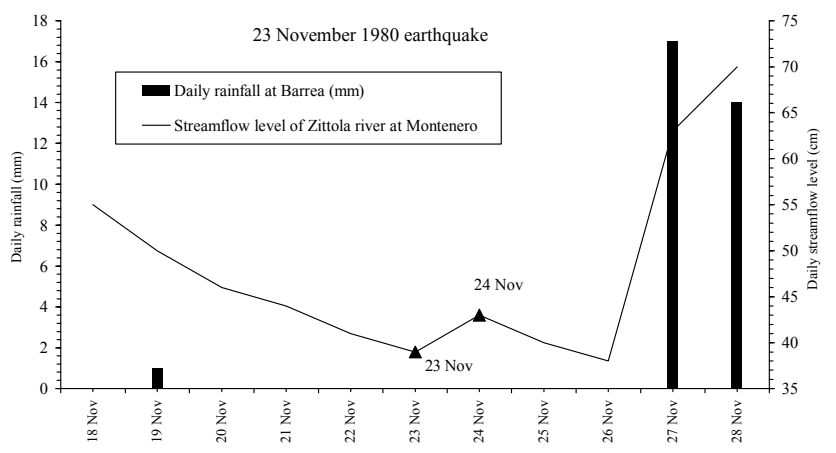

Fig. 5. Hydrological anomaly correlated to the 23 November 1980 earthquake, consisting of an increase in the streamflow rate of Zittola River measured at Montenero, not imputable to rainfalls.

starting from 24 November, lasting for about $24-48 \mathrm{~h}$. In some cases, the positive anomaly lasted until 27 November.

A detailed study of the spring flows at Caposele and Cassano Irpino, located near the epicentre, have been carried out, by considering the monthly averages in 10 years (Pece et al., 1999). The year 1980 appears to be hydrologically anomalous.

Figures 4 to 9 show some hydrological anomalies.

In Fig. 4 the anomaly consists of the great increase in the flow rate of a thermal spring (Acqua Fetente) between 17 and 30 November (earthquake was on 23 November) and this increase lasted many months. All this behaviour is anomalous and the rainfalls could not produce such a sudden and great increase. It is sufficient to observe what is the contribution of each rainfall event on hydrograph of the flow rate. We suppose that the pre- and co-seismic stresses modified the groundwater circulation.

In Fig. 5 there is another type of anomaly. Measurements are carried out on the mountain stream by a river gauge and the continuous record shows that a decrease is followed by an increase recorded at 12:00 MLT each day. It is not possible that this increase is due to some rainfall (no rainfalls are present in 23 and 24 November). The response of water level to rainfalls in this site is almost contemporaneous, because 


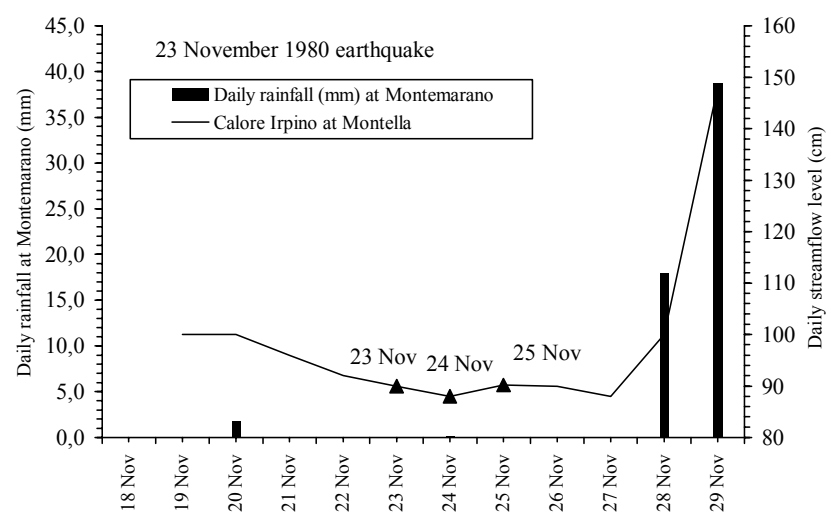

Fig. 6. Hydrological anomaly correlated to the 23 November 1980 earthquake. In this case the streamflow level of Calore Irpino measured daily at Montella decreased the day after the earthquake.

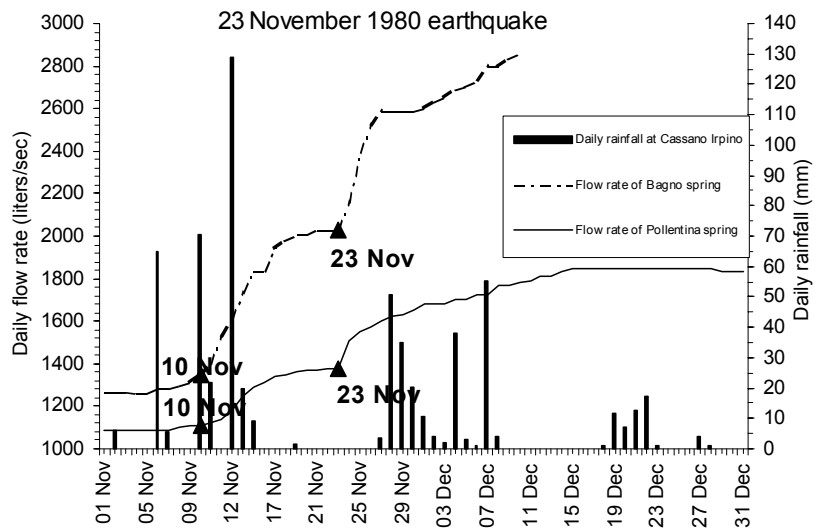

Fig. 7. Hydrological anomalies correlated to the 23 November 1980 earthquake consisting of the strong increase in the flow rate of Pollentina and Bagno Springs.

the catchment area of rainfall is small (see 27 November). So the increase between 23 and 24 November appears to be imputable only to the seismic event.

In Fig. 6 the anomaly seems to be the opposite of that shown in Fig. 5. In fact, there is a decrease from 23 to 24 November: the increase took place on 25-26 November. Also in this case, no rainfalls occurred in those days. The decrease at this site can be explained by taking into account that near Caposele Spring, the same behaviour is exhibited (Fig. 9).

Figure 7 shows the hydrological anomalies consisting of the strong increase in flow rate of Pollentina and Bagno Springs, very near each other at Cassano Irpino. It seems that this increase started about ten days before the seismic event. A further sharp increase took place soon after the earthquake. We retain that these increases cannot be imputable to the rainfalls that preceded the seismic event. In fact, Fig. 8 shows the trends of monthly cumulated flow rates of these two springs compared to the rainfalls in the decade 1975-1985. This figure also reports the flow rate of the Caposele Spring. The lag among rainfalls and increases in the

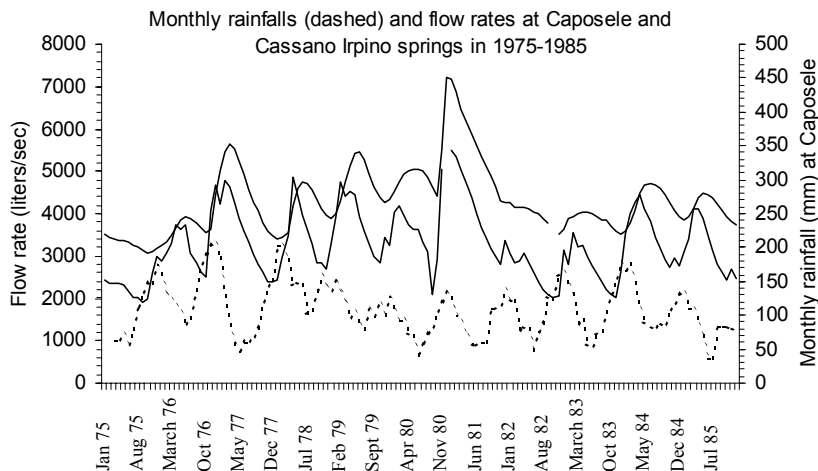

Fig. 8. Monthly rainfalls (dashed) and flow rates at Caposele and Cassano Irpino Springs in 1975-1985 showing the lag between rainfalls and subsequent increase in flow rate.

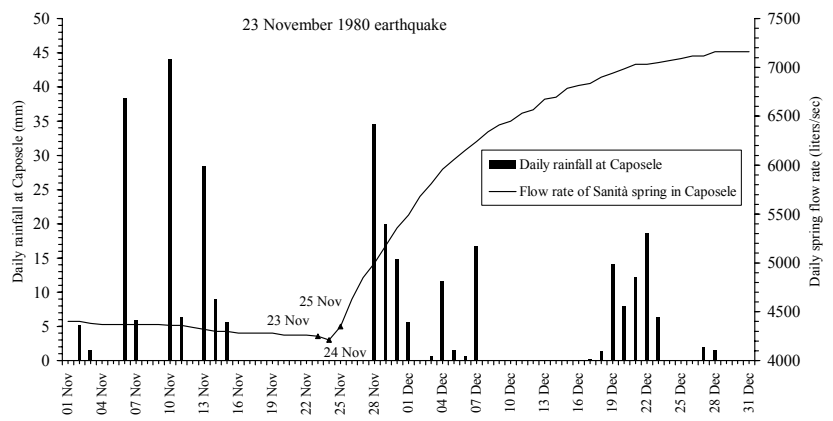

Fig. 9. Hydrological anomaly correlated to the 23 November 1980 earthquake consisting of a small decrease in the spring flow rate the day after the earthquake, followed by a very great increase.

flow rates is consistent: some months, with Caposele preceding Cassano Irpino. This evidence has been already reported by many authors (Celico, 1981; Cotecchia and Salvemini, 1981).

In Fig. 9 the hydrological anomaly at Caposele consists of a small decrease in the spring flow rate the day after the earthquake, followed by a very great increase.

\subsection{The earthquake of May 1984}

The seismic sequence, which started in May 1984, consists of two main shocks, on 7 May and on 11 May with I = VII MSK in Southern Abruzzo, mainly in the National Park seismogenetic zone (Alessio et al., 1993). The hypocentral depths are between 5 and $15 \mathrm{~km}$. The seismic sequence terminated in October with a duration of about 5 months.

In order to evaluate the hydrological effects produced by the seismic sequence, we analysed the data registered in 15 hydrometrical stations and the variations of levels of two lakes (Barrea and Scanno), all localised in the epicentral area and monitored by the National Hydrologic Departments in Napoli and Pescara.

Hydrological variations have been registered in 12 hydro- 


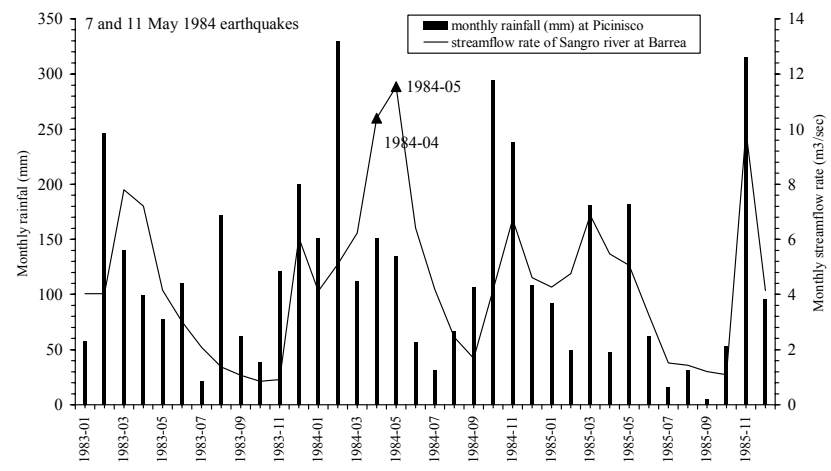

Fig. 10. Hydrological anomaly correlated to the May 1984 earthquake consisting of an increase in the streamflow rate of Sangro River at Barrea, not imputable to the rainfalls. Data are monthly.

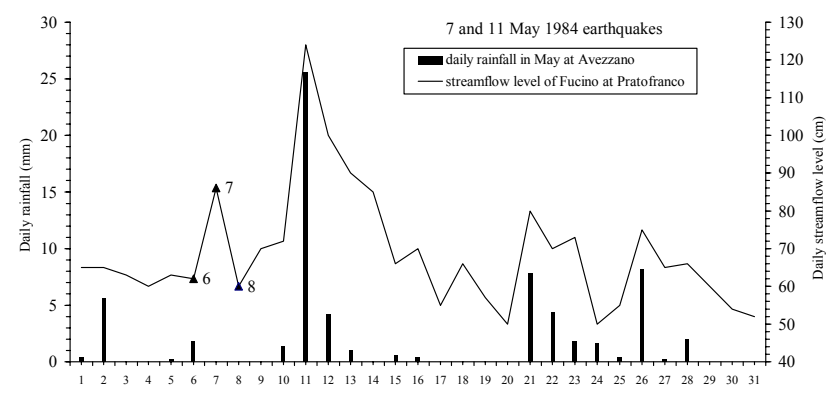

Fig. 11. Hydrological anomaly correlated to the May 1984 earthquake consisting of an increase in the streamflow rate of Fucino River at Pratofranco, not imputable to the rainfalls. Data are daily.

metric sections. Among them, 3 hydrometric stations WSW in the epicentral area, and another station located west of the continuation toward north of the Val di Sangro fault did not show notable hydrological anomalies in the days before the event of 7 May, while during all this month, flow rates were comparable with the average values calculated for the period 1979-1989, even if the rainfalls from January to May 1984 have been slightly higher than the average (Onorati and Tranfaglia, 1994).

Nevertheless, gas outpouring and the muddying of water have been noticed in the evening of 5 May, in the springs at Posta Fibreno, localized about $2 \mathrm{~km}$ before the hydrometric sections (Fibreno at Broccostella).

Also in the hydrometric section of the Sangro River at Ateleta, the hydrological anomaly was pointed out only in the value of the average streamflow level in May 1984. Consequently, for these earthquakes, we have a total of 14 sites where hydrological effects have been noticed, taking into account that in 3 sites (the Rapido and Gari Rivers at Cassino, the Gari River at S. Angelo in Theodice), the positive hydrological anomalies preceded the earthquake of 7 May.

Figures 10 and 11 show the anomalous behaviour in two studied sites. In Fig. 10 we show an hydrological anomaly consisting of a strong increase in the streamflow rate of the Sangro River at Barrea, not imputable to the rainfalls. Fig- ure 11 shows "a detail" of Fig. 10. The two sites are very near each other. It shows how during April 1984 the sharp increase of 7 May cannot be imputed to the very small rainfalls on 6 May. Data are daily.

\section{Conclusions}

In the southern Apennines we found that some earthquakes produced forerunner signals in various areas where geochemical and hydrological parameters were controlled. These results seem to indicate that the hydrological phenomena are associated with the changes in the stress field, during and after an earthquake.

We analysed the relations of primary tectonic effects with the local geomorphic and structural setting. We also applied, for some categories of secondary effects, a statistical test to infer the presence of trends, and a regression analysis based on the least-squares method was performed.

In particular, a simple bivariate scatter plot of two variables has been computed, specifically: macroseismic intensities versus epicentral or fault distances of hydrological anomalies. Figure 12 shows, for each of the 4 considered earthquakes, the trend macroseismic intensity-distance from the epicenter of the hydrological anomalies we have found (30 for 1805 earthquake, 65 for 1930 earthquake, 35 for 1980 earthquake and 21 for 1984 earthquake). Very similar trends have been found for these earthquakes with a better fit for the two most recent earthquakes (1980 and 1984).

Hydrological phenomena occurred throughout the macroseismic field, and were the most numerous among the induced effects. They include flow increase both in springs and wells, turbid water and drying up of springs, and even creation of new springs. Some variations in the chemical parameters of the waters were observed at different locations, both inside and outside the epicentral areas.

The data relative to the hydrological variations' distribution versus the distance from the epicenter (Fig. 12) show the that the high concentration of phenomena $(75 \%)$ lie between $25-80 \mathrm{~km}$, whereas $19 \%$ were inside the epicentral area $(0$ $25 \mathrm{~km}$ ); only $6 \%$ of these phenomena occurred at greater distances (about $100 \mathrm{~km}$ ); this distribution is very similar to those reported by Kissin and Grinevsky (1990).

A dramatic increase in the springs' flow implies the deformation of a major tectonic block. A comparable phenomenon occurred at the Sanità Spring near Caposele during the 23 November 1980 earthquake.

A remarkable aspect of these anomalies is that they were observed at distances of several hundred kilometres from the earthquake epicentral area.

Figure 12 shows that much more data on hydrological changes are available for the 1980 earthquake compared to the 1805 earthquake. Even taking into account the better accuracy of the research conducted after the 1980 event, this suggests that the impact of the Irpinia earthquake on the hydrogeological structure of the southern Apennines was more 

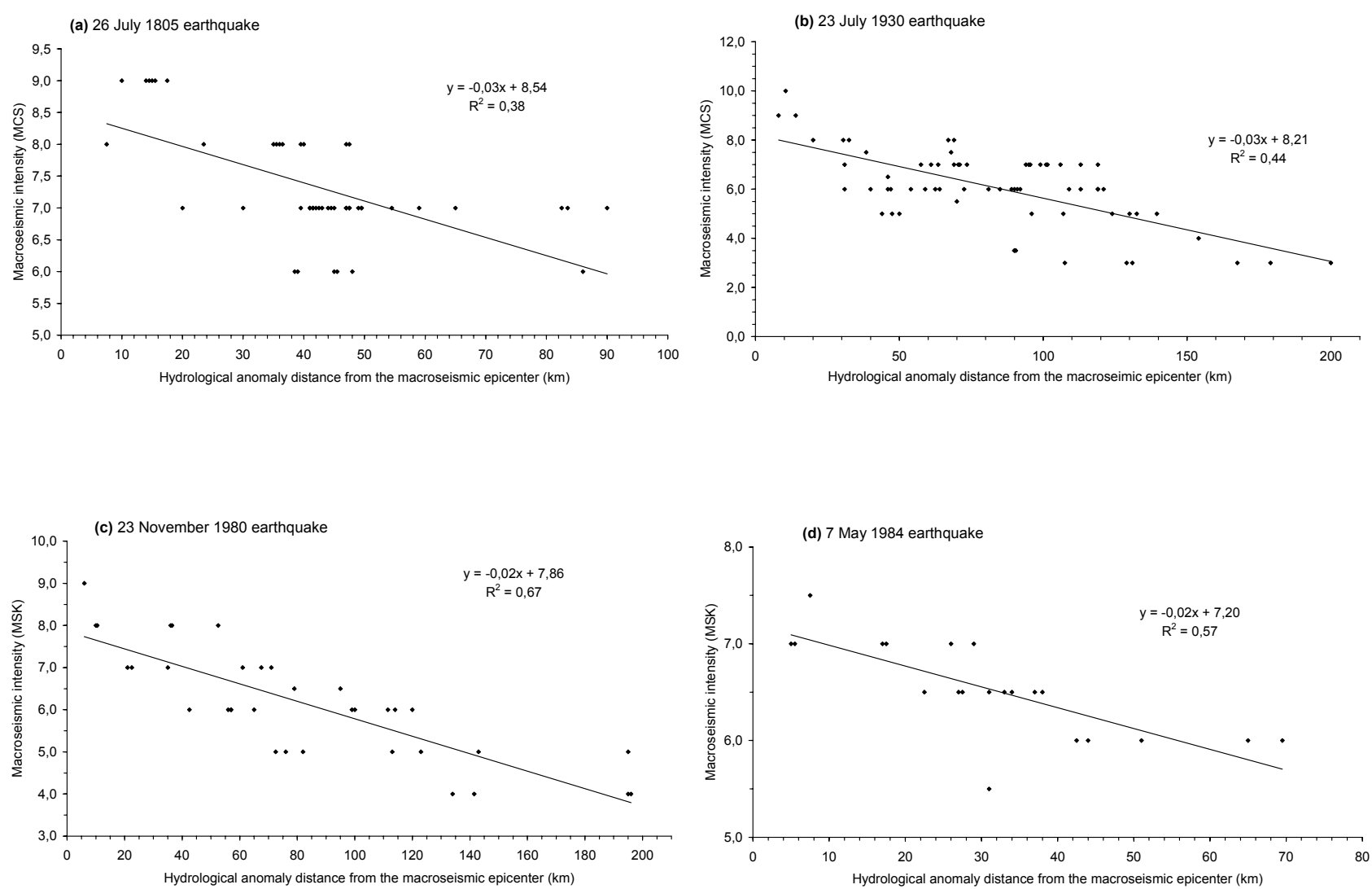

Fig. 12. The figure shows for each earthquake the distance from epicenter and intensity (MCS or MSK) of the sites where hydrological anomalies have been observed. A clear negative linear regression is visible. For the $1930(M=6.5)$ and $1980(M=6.8)$ earthquakes the two trends are parallel.

important, in terms of both the total number of recorded anomalies and for their epicentral and fault distance.

Today, there are no valid earthquake precursors, but many effects are invoked as good forerunners: geophysical changes $\left(v_{p} / v_{s}\right.$, telluric currents, electromagnetic effects), geochemical changes (chemical composition, $\mathrm{pH}$, water temperature, gases like $\mathrm{Rn}, \mathrm{CO}_{2}$ ) and hydrological changes (piezometric levels, spring and stream flow).

In this work we show hydrological anomalies for the considered Italian earthquakes similar in "form and type" to those reported by previous authors in other regions of the Earth. They are examples of the many anomalies we have chosen for the considered earthquakes (see Fig. 12) and show how hydrological anomalies are made. Probably the simultaneous observation of all of these effects can constitute a sure forecasting. Many efforts and money are necessary for this purpose.

Taking into account that earthquakes are not always preceded by all of the above mentioned precursory phenomena, and that today's technology can provide probes for many geochemical and geophysical parameters at an affordable cost, we maintain that a regional monitoring network can be installed in order to continuously control as many parameters as possible.

The presence of an already installed hydrological network at the Hydrographic National Service in Campania can furnish a valid occasion to increase the number of parameters to monitor water tables and springs.

We envisage that the proposed improvement of this network can reveal many and contemporaneous anomalies in the trends of the monitored parameters; the examination of trends and anomalies are fundamental in order to produce a valid model of the interaction between stress fields and hydrological behaviour in the monitored areas; this model can be considered reliable in order to verify the occurrence of pre-seismic anomalies.

\section{References}

Albarello, D. and Martinelli, G.: Piezometric levels as possible geodynamic indicators: analysis of data from a regional deep waters monitoring network in northern Italy, Geoph. Res. Lett., 21, 18, 1955-1958, 1994.

Albarello, D., Ferrari, G., Martinelli, G., and Mucciarelli, M.: Well level variation as a possible seismic precursor: a statistical assessment from Italian historical data, Tectonophysics, 193, 385395, 1991.

Alessio, G., Godano, C., and Gorini, A.: A low magnitude seismic sequence near Isernia (Molise, central Italy) on January 1986, PAGEOPH, 134, 2, 243-260, 1990. 
Alessio, G., Esposito, E., Gorini, A., Luongo, G., and Porfido S.: Identification of seismogenic areas in the southern Apennines, Italy, Annali di Geofisica, 36, 1, 227-235, 1993.

Alessio, G., Esposito, E., Gorini, A., and Porfido, S.: Detailed study of the Potentino seismic zone of the southern Apennines, Italy, Tectonophysics, 250, 113-134, 1995.

Bredehoeft J. D., Riley F. S., and Roeloffs E. A.: Earthquakes and Groundwater. Earthquakes and Volcanoes, 19, 4, 142-146, 1987.

Briggs, R. O.: Effects of the earthquakes on surface waters in Waddell Valley. In: The Loma Prieta (California) Earthquake of 17 October 1989 - Hydrologic disturbances, USGS Prof. Paper 1551-E, 21-30, 1994.

Celico, P.: Relazioni tra idrodinamica sotterranea e terremoti in Irpinia (Campania), Rendiconti Società Geologica Italiana, 4, 103-108, 1981.

Chengmin, W.: Ground-water studies for earthquake prediction in China, Pageoph, 122, 215-217, 1985.

Cotecchia, V. and Salvemini A.: Correlazione fra eventi sismici e variazioni di portata alle sorgenti di Caposele e Cassano Irpino, con particolare riferimento al sisma del 23 novembre 1980, Geologia Applicata e Idrogeologia, XVI, 167-191, 1981.

Curry, R. R., Emery B. A., and Kidwell T. G.: Sources and Magnitudes of increased streamflow in the Santa Cruz Mountains for the 1990 water year after the earthquake, In: The Loma Prieta (California) Earthquake of 17 October 1989 - Hydrologic disturbances, USGS Prof. Pap. 1551-E, 31-50, 1994.

Esposito, E., Luongo, G., Maturano, A., and Porfido, S.: Il Terremoto di S. Anna del 26 luglio 1805, Mem. Soc.Geol. It., 37, 171-191, 1987.

Esposito, E., Laurelli, L., and Porfido, S.: Damage pattern in historical centres: Isernia an example in Southern Italy, Annali di Geofisica, 38, 663-677, 1995.

Esposito, E., Porfido, S., Tranfaglia, G., and Avino, R.: Effetti idrologici associati con i terremoti dell'Appennino meridionale, Atti $16^{\circ}$ Conv. GNGTS, Trieste, 1998a.

Esposito, E., Gargiulo, A., Iaccarino, G., and Porfido, S.: Distribuzione dei fenomeni franosi riattivati dai terremoti dell'Appennino meridionale. Censimento delle frane del terremoto del 1980, Proc. Conv. Int. Prevention of Hydrogeological Hazards: the role of scientific research 1, CNR-IRPI, Alba, 409429, 1998b.

Esposito, E., Pece, R., Porfido, S., Tranfaglia, G., and Onorati, G.: Effetti dei terremoti dell'Appennino meridionale sulle acque superficiali, Atti Acc. Naz. Lincei, 154, 91-96, 1999.

Esposito, E., Porfido, S., Iaccarino, G., and Tranfaglia, G.: Terremoti e centri storici dell'Irpinia: gli effetti del terremoto del 1930, Proc. GeoBen 2000, CNR-GNDCI, 2133, 477-484, 2000.

Gold, T. and Soter, S.: Fluid ascent through the solid lithosphere and its relation to earthquakes, Pageoph., 122, 2/4, 492-530, 1985.

Igarashi, G., Wakita, H., and Sato, T.: Precursory and coseismic anomalies in well water levels observed for the 2 February 1992 , Tokyo Bay earthquake, Geoph. Res. Lett., 19, 15, 1583-1586, 1992.

King, G. C. P. and Muir-Wood, R.: Hydrological Signatures of Earthquake Strain, Jour. Geoph. Res., 98 (B12), 22 035-22 068, 1993.

Kissin, I. G. and Grinevsky, A. O.: Main features of Hydrogeodynamic earthquake precursors, Tectonophysics, 178, 277-286, 1990.

Michetti, A. M., Blumetti, A. M., Esposito, E., Ferreli, L., Guerrieri, L., Porfido, S., Serva, L., and Vittori, E.: Earthquake Ground Ef- fects and Seismic Hazard Assessment in Italy: examples from the Matese and Irpinia areas, southern Apennines, In: Active Fault Research for the New Millennium, Proc. Hokudan Symposium and School on Active Faulting, 279-284, 2000.

Mogi, K.: Comparison of precursory phenomena before the 1975 Haicheng (China) earthquake and the 1978 Izu-Oshima-Kinkai (Japan) earthquake: the possible effect of stress history on precursory phenomena, Tectonophysics, 138, 33-43, 1987.

Molnar, P., Hanks, T., Nur, A., Raleigh, B., Wu, F., Savage, J., Scholz, C., Craig, H., Turner, R., and Bennet, G.: Prediction of the Haicheng earthquake, "The Haicheng Earthquake Study Delegation” Report, 1976.

Muir-Wood, R. and King, G. C. P.: The impact of earthquakes on fluids in the crust, Annali di Geofisica, XXXVII, 6, 1453-1460, 1994.

Onorati, G. and Tranfaglia, G.: L'anomalia idrologica che ha preceduto i terremoti del maggio 1984 nel Parco Nazionale d'Abruzzo, Acc. Naz. Lincei. Convegno su "Terremoti in Italia: previsione e prevenzione dei danni”, 1994.

Onorati, G. and Tranfaglia, G.: La rete di telemisura del bacino idrografico del fiume Sele: esperienze di monitoraggio delle piene - Atti Conv. Int. "revenzione delle catastrofi idrogeologiche: il contributo della ricerca scientifica", Alba, November, 1996.

Onorati, G., Pece, R., Tranfaglia, G., and Zollo, A.: Sismicità e regime delle falde acquifere nell'Appennino meridionale, Atti $13^{\circ}$ Conv. Naz. GNGTS, Roma, 895-906, 1994.

Pece, R., Tranfaglia, G., and Avino, R.: Geochemical monitoring integrated in a real time hydrological network, Il Nuovo Cimento, 22 C, 483-490, 1999.

Porfido, S., Esposito, E., Iaccarino, G., Pece, R., Tranfaglia, G., Esposito, G., and Alaia, F.: Ground effects during the 23 July 1930 Irpinia earthquake (southern Italy), Geophys. Res. Abst., 3, 2001 - 26th General Assembly, Nice, France, 2001.

Rikitake, T. (Ed): Focal processes and prediction of earthquakes Tectonophysics, 23, 217-318, 1974.

Rikitake, T.: Earthquake Precursors - Bulletin of the Seismological Society of America, 65, 5, 1133-1162, 1975.

Rojstaczer, S. and Wolf, S.: Hydrologic changes associated with the earthquake in The San Lorenzo and Pescadero drainage basins, In: The Loma Prieta (California) earthquake of 17 October 1989 - Hydrologic disturbances, USGS Prof. Paper 1551-E, 51-64, 1994.

Savaresky, E. F. and Rikitake T. (Eds): Forerunners of strong earthquakes - Tectonophysics, 14, 3/4, 177-343, 1972.

Scandone, P., Patacca, E., Meletti, E., Bellatalla, C., Perilli, N., and Santini, U.: Struttura geologica, evoluzione cinematica e schema sismotettonico della penisola italiana, Atti Convegno GNDTCNR, 1, 119-136, 1990.

Scholtz, C. H., Sykes, L. R., and Aggarwal, Y. P.: Earthquake prediction: A physical basis, Science, 181, 803-810, 1973.

Thomas, D.: Geochemical precursors to seismic activity - Pageoph, 126, 2/4, 241-266, 1988.

Tranfaglia, G.: Realizzazione di una rete idrometeorologica in teletrasmissione nei Bacini del Liri-Garigliano e del Volturno - Atti del Convegno "Atmospheric Physics and Dynamics in the Analysis and Prognosis of Precipitation Fields", Rome, 15-16 November 1994.

Whitehead, R. L., Harper, R. W., and Sisco, H. G.: Hydrologic changes associated with the 28 October 1983, Idaho earthquake, Pageoph, 122, 280-293, 1985. 